\title{
DEVELOPING ESP NURSING \\ BASED ON COMMUNICATIVE LANGUAGE TEACHING
}

\author{
Yoyok Febrijanto, Sandy Kurniajati \\ STIKES RS Baptis Kediri \\ fyoyok@yahoo.co.id
}

\begin{abstract}
ESP nursing materials is an important component in the success of educational programs, especially in the field of nursing. The development of English learning is now emphasis on the authenticity of the material that is contextual activities or work involved, one of which is in nursing profession. Communicative language teaching (CLT) sets principles about the teaching of communicative competence that does not only confine to verbal communication but also includes written communication. It consists of four skills especially on ESP nursing based on nursing care (assessment, nursing diagnosis, planning(intervention \& implementation, and evaluation) as the main source of objective achievement in teaching learning process. The development method used is adapted from Borg and Gall's model involved 24 students, 1 expert in English education, 2 experts in nursing education, and 1 practitioner of hospital. Researchers developed materials (4 chapters) based needs analysis (students' need and reviewing existing syllabus) with four language skills. Result of expert validation (materials evaluation based on contents, exercises, communication, and general elements) was very good (average score 3.5) and result of students' try out to give the decision of the product quality, the average score was 3.2. It means the materials was acceptable and eligible to be used by the nursing students as autonomous learning. In conclusion, the final product can be used as a model of instructional materials to teach English nursing as ESP materials.
\end{abstract}

Keywords: ESP Nursing, CLT, Material Development

\section{INTRODUCTION}

An instructional material (ESP Nursing) is one important component in the success of educational programs, especially in the field of nursing. The development of learning English is now more emphasis on the authenticity of the material that is contextual activities or work involved, one of which is in nursing profession. The learning in the context of real (natural) is more effective than learning English focused on mastery of grammatical competence. Some textbooks/course books, there is no longer compatible with the latest developments in language learning theory, for example, in the textbooks/course 
| Volume: 2 | Number: 2 | October 2017 | E-ISSN: 2503 - 4405| P-ISSN: 2580-3441|

books still feature-based grammar lessons. The weakness, when students are directly involved in the context of real communication, they are not able to speak fluently and accurately, in other words the need for improved communication competence is huge demand.

Principles of Communicative Language Teaching

According to Richard (2006: 2-5), communicative language teaching (CLT) can be understood as a set of principles about the goals of language teaching, how learners learn a language, the kinds of classroom activities that best facilitate learning, and the roles of teachers and learners in the classroom. CLT sets as its goal the teaching of communicative competence. Communicative competence includes the following aspects of language knowledge: (1) Knowing how to use language for range of different purposes and functions. (2) Knowing how to vary our use of language according to the setting and the participants (e.g. knowing when to use formal and informal speech or when to use language appropriately for written as opposed to spoken communication). (3) Knowing how to produce and understand different types of texts (narratives, reports, interviews, conversations), and (4) knowing how to maintain communication despite having limitations in one's language knowledge (e.g. through using different kinds of communication strategies).

In recent years, language learning has been viewed from a very different perspective. It is seen as resulting from processes such as: (1) interaction between the learner and users of the language, (2) collaborative creation of meaning, (3) creating meaningful and purposeful interaction through language, (4) negotiation of meaning as the learner and his or her interlocutor arrive at understanding, (5) learning through attending to the feedback learners get when they use the language, (6) paying attention to the language one hears (the input) and trying to incorporate new forms into one's developing communicative competence, and (7) trying out and experimenting with different ways of saying things.

The kinds of classroom activities that best facilitate learning with CLT began a movement away from traditional lesson formats where the focus was on mastery of different items of grammar and practice through controlled activities 
| Volume: 2 | Number: 2 | October 2017 | E-ISSN: 2503 - 4405| P-ISSN: 2580-3441|

such as memorization of dialogs and drills, and toward the use of pair work activities, role-plays, group work activities and project work.

The type of classroom activities proposed in CLT also implied new roles in the classroom for teachers and learners. Learners now had to participate in the classroom activities that were based on cooperative rather than individualistic approach to learning. Students had to become comfortable with listening to their peers in group work or pair work tasks, rather than relying on the teacher for a model. They were expected to take on a greater degree of responsibility for their own learning. Teachers now had to assume the role of facilitator and monitor. Rather than being a model for correct speech and writing and one with the primary responsibility of making students produce plenty of error-free sentences, the teacher had to develop a different view of learners' errors and of her/his own role in facilitating language learning.

Communication is now not limited to oral communication but also includes written communications. Communication consists of four skills of reading and listening skills as receptive as well as productive speaking and writing skills. For nursing students have the language skills that match the competency of nursing, especially in nursing care (assessment, nursing diagnosis, intervention \& implementation, evaluation) is necessary, because the challenges of the working world in the era of ASEAN Economic Community (AEC) requires nurses have the skills/competency to communicate English in the line of duty nursing.

CLT is a method of teaching and learning. The purpose of this method is to guide students have English skills better. This method is also intended to achieve communicative competence. Its competence is designed through the implementation of student centered learning in the classroom. The idea of student-centered learning is shown through task-based language teaching (TaskBased Language Teaching- TBLT) as the core of the communicative approach or CLT. The important concept in this approach is to engage students in real world communication through a series of communicative duties with the balance between fluency and accuracy (Harmer, 2007: 69). Teachers provide communicative task to give description that build student competence in producing and enriching the English proficiency on nursing. To achieve 
| Volume: 2 | Number: 2 | October 2017 | E-ISSN: 2503 - 4405| P-ISSN: 2580-3441|

communicative competence as a goal in language classes, Brown (2007: 79) states that there are four kinds of communicative competence that teachers should pay attention to, (1) organizational competence (discourse grammar), (2) pragmatic competence (functional and sociolinguistic), (3) strategic competence, (4) psychomotor ability. Those our competences towards the principle that the same accuracy is important with eloquence have the feeling that the language used accurately, fluently, and acceptably.

Several factors affect the characteristics of the CLT. Brown (2007: 46) defines the following characteristics: (1) overall goal, focus to all destinations within the communicative competence. (2) relationship of form and language function, this technical is designed by asking students to use as a pragmatic, authentic, and function for meaning purposes. (3) fluency and accuracy, focus to students comprehensive process and production focusing on accuracy based techniques communication. (4) focus on real-world communication context, students in the class required to use the target language either both receptive and productive in context without preparatory training held outside class. (5) autonomy and strategic involvement, the students were given the opportunity to focus on the learning process itself through increased awareness according to the learning style and through the development of strategies that fit the expected results and comprehension. (6) Teacher's role, teacher's role is as facilitator and mentor, not the person of who knows everything. (7) Student's role, students actively participate in language learning independently both in class and outside class.

Characteristics of task-based language teaching (TBLT) as the core of the communicative approach, TBLT and content-based instruction involves students not only focus on the form of the language or the language itself, but also focus on how to use the language in communicative interactions, conversations, and the use of language (Lightbown and Spada, 2001: 92). In fact, in a social context or in the workplace, it is almost impossible to ask students about the structure of language such as the present tense, past tense, simple passive sentences, and grammar. What happens in the interaction between people is based on science that has students. However, it does not mean that the grammar is not necessary in 
| Volume: 2 | Number: 2 | October 2017 | E-ISSN: 2503 - 4405| P-ISSN: 2580-3441|

the real world communication. TBLT not mean grammar totally ignored by paying priority meaning in communication. There are two approaches applied in TBLT to make an accurate and objective communicative activities: focused approach focused approach forms and meanings. Focus on form comes before the students engage in communicative activities. The purpose of this method is intended communicative students can apply the structures they have learned in real-world tasks. Educators try to teach students about grammar communicative to limit inaccuracies although they are welcome when generating a language with many inaccuracies. Educators give students the opportunity to use the language in the classroom to authentic communication with a focus on the meaning (Willis and Willis, 2007: 4).

Principles of Materials Development

There are sixteen principles that Tomlinson (1998:7-21) summarizes of what he thinks many SLA researchers would agree to be the basic principles of SLA rlevant to the materials development for the teaching of languages. These principles are briefly outlined in this section. They are as follow:

1. Materials should achieve impact.

2. Materials should help learners to feel at ease.

3. Materials should help learners to develop confidence.

4. What is being taught should be perceived by learners as relevant and useful.

5. Materials should require and facilitate learner self-investment.

6. Learners must be ready to acquire the points being taught.

7. The learners' attention should be drawn to linguistic features of the input.

8. Materials should provide the learners with opportunities to use the target language to achieve communicative purposes.

9. Materials should take into account that the positive effects of instruction are usually delayed.

10. Materials should take into account that learners differ in learning styles.

66| ENGLISH EDUCATION 
| Volume: 2 | Number: 2 | October 2017 | E-ISSN: 2503 - 4405| P-ISSN: 2580-3441|

11. Materials should take into account that learners differ in affective attitudes.

12. Materials should permit a silent period at the beginning of instruction.

13. Materials should maximize learning potential by encouraging intellectual, aesthetic and emotional involvement, which stimulates both right and left brain activities.

14. Materials should not rely too much on controlled practice.

15. Materials should provide opportunities for outcome feedback.

16. Teachers preparing instructional materials based communication competence, as a source of learning for students is a challenge.

An instructional material is one important component in the success of the education program. Instructional materials referred to in the form of textbooks, teaching materials (textbooks), or instructional media plays an important role in teaching. Textbooks should serve as towing the interest and motivation of learners and readers. Motivation reader can arise because the language is simple, flowing and easy to understand. Motivation can arise due to many ideas and new ideas. Motivation can arise, because the textbook contains a variety of information that is relevant to the needs of learners and readers. Teaching materials (textbooks) is a handbook of the course, prepared by experts related fields, meet the standards of textbooks, officially published, and disseminated (Arifin\&Kursrianto, 2009: 58). In English teaching on nursing, teaching materials compiled based communication competence is seen as the main source in the achievement of objectives in teaching and learning.

\section{MATERIAL AND METHOD}

The research design was research and development (R\&D). According to Latief (2013:171), "educational research and development is a research design aimed at developing educational products, like curriculum, syllabus, textbooks, instructional media, modules, assessment instrument, etc". The objective is to develop ESP Nursing material uses communicative English language teaching based on nursing care (assessment, nursing diagnosis, intervention 
| Volume: 2 | Number: 2 | October 2017 | E-ISSN: 2503 - 4405| P-ISSN: 2580-3441|

\&implementation, and evaluation). The development method used is adapted from Borg and Gall's model. The product was course book for 3-year nursing study program in second semester at STIKES RS Baptis Kediri. The research involved 24 students and 1 expert of English education, 2 experts of nursing education, as well as 1 hospital practitioner. Development model is based on Borg and Gall's model. (1986) in Gunadi (2011: 58-59). The researchers proposed R\&D cycle as follow: (1) student's need analysis, (2) developing materials, (3) validation by experts, (4) revision, (5) and try out the product. A model of framework fordeveloping instructional material (ESP nursing) is presented below.

Student Needs Analysis

(1) Giving questionnaires to collect students' need, (2) Observation to the learning situation, and (3) Reviewing literature, reviewing the contents of the existing syllabus, and other relevant sources.

\section{$\llbracket$}

Development ESP Nursing Using Communicative Language Teaching (CLT)

(1) Making learning objectives, (2) Selecting topics and sub-topics, (3) Mapping material through FGD (Focus Group Discussion), and (4) Searching for relevant resources.

几

Validation by Experts

(1)Giving draft products to the experts and (2)The collection of data from experts.

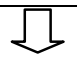

Revision

(1) Revise the material based on the collection of data from experts.

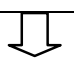

Try out The Product

(1) Try out the product in a real classroom, and (2) The collection of data from student to determine the acceptability of the product.

Figure 1. Material Development Model adapted from Borg and Gall (1986).

68| ENGLISH EDUCATION

Journal of English Teaching and Research 


\section{RESULT AND DISCUSSION}

\section{Obtaining Information}

In this step, the researchers gave questionnaire obtaining information to 24 students who take English for Nursing in second semester. The questionnaire was given to the students at March 6, 2017. The data from the result of need analysis showed that most students agree to develop English materials that are suitable and related to their nursing profession with four language skills. This questionnaire consisted of 6 questions related to the students' prior knowledge in English, students' motivation, students' learning strategy, teacher's teaching methods, classroom environment, and classroom facilities. Through their answer in the questionnaire, it was found data as served below:

Table 1. Students' Prior Knowledge

\begin{tabular}{|c|c|c|}
\hline Items & Modus & Interpretation \\
\hline \multicolumn{3}{|c|}{ Student's Prior Knowledge } \\
\hline a) & 3 & There were students who had poor listening skill previously $(16,7 \%)$ \\
\hline b) & 3 & There were students who had poor speaking skill previously $(12,5 \%)$ \\
\hline c) & 3 & Students had good reading skill previously $(91,7 \%)$ \\
\hline d) & 3 & There were students who had poor writing skill previously $(12,5 \%)$ \\
\hline e) & 3 & $\begin{array}{l}\text { There were students who had poor on vocabulary mastery previously } \\
(16,7 \%)\end{array}$ \\
\hline f) & 3 & $\begin{array}{l}\text { There were students who had poor learning/practicing grammar } \\
\text { previously }(12,5 \%)\end{array}$ \\
\hline g) & 2 & There were students who didn't want to increase the grade $(16,7 \%)$ \\
\hline
\end{tabular}

It means that they had already had English knowledge previously. The researcher assumed that they learned and practiced 4-communication skills priority in listening, speaking, reading, writing skills, because they thought English's knowledge was important to support their profession as nurse.

Listening, speaking, and writing were the most important to develop in this subject. For nurses, listening was part of nurse's duty because through this skill, they listened some complains from patients and orders or advises as collaboration intervention from doctors. Speaking and writing were also the priority for them; 
| Volume: 2 | Number: 2 | October 2017 | E-ISSN: 2503 - 4405| P-ISSN: 2580-3441|

they thought that speaking was important for their field and future carrier as a nurse. The students knew that speaking was important for their field. They wanted to use their background knowledge to improve their communication; they believed that their background knowledge was useful for them to develop their speaking skill. For writing skill, based on this condition, the researchers developed writing exercises in instructional material, which use communicative language teaching without leaving learning grammar. In this case, the students' constructivism (their own knowledge by testing ideas based on prior knowledge and experience) used in writing. Some authentic pictures help them to develop their writing well. There were real writing and display writing in writing skill. In nursing, nurses had duty to make patient's documentation during nursing process. This strategy was similar with what Brown (2007:396) says that writing to display one's knowledge is a fact of life in the classroom, and can help the students get succeed in further academic pursuits. As a new subject, sometimes reading material helped the students because there were some medical/nursing terminology vocabularies but the students believed that reading was important thing in their knowledge. Reading comprehension can be significantly enhance if background knowledge can be active by setting goal, asking questions, making predictions, teaching next structure, and so on. Reading class should give benefit to the students. The reading material given should relate to students background knowledge suppose they got easily understanding.

Table 2. Student's Motivation

\begin{tabular}{|l|l|l|}
\hline Items & Modus & Interpretation \\
\hline \multicolumn{2}{|l|}{ Student's Motivation } \\
\hline a) & 2 & Students have high motivation in listening $(95,8 \%)$ \\
\hline b) & 2 & Students have high motivation in speaking $(95,8 \%)$ \\
\hline c) & 2 & Students have high motivation in reading $(95,8 \%)$ \\
\hline d) & 2 & Students have high motivation in writing $(91,7 \%)$ \\
\hline e) & 1 & Students think communication skills important $(95,8 \%)$ \\
\hline f) & 2 & Students do not have motivation from classmates $(20,8 \%)$ \\
\hline
\end{tabular}


From the data above, the researcher got the result of questionnaire for obtaining information about students' motivation was high and important on every skill, but their classmates and close friends rarely motivate them to practice communication skills.

In other words that they had motivation to learn English because they had opportunity to practice, they were interested, they had self-motivation by developing communication skills and their classmates or close friends support each other. The researcher assumed that the students had positive motivation because they were interested to practice communication skills orally or written with their classmates and friends in any opportunity. According to Latief (2001) the constructivist learning model treated students as active participants rather than passive recipients of information. The constructivist message suggested that students who were engaged in active learning were making their own meaning and constructing their own knowledge in the process. Students made meaning of their learning experiences through interactions with teachers, parents, the community, and each other.

Based on students' need, the researcher gave some practice communication materials, which have correlation to their field, and the things related to their future job in course book. The researcher developed various activities to arise students' motivation such as brainstorming, work in pairs, small group discussion, discover learning, role play/performance and presentation.

Table 3 Student's Learning Strategies

\begin{tabular}{|l|l|l|}
\hline Items & Modus & Interpretation \\
\hline \multicolumn{2}{|l|}{ Student's Learning Strategies } \\
\hline a) & 2 & $\begin{array}{l}\text { Students learn English through songs, news, or recording from in } \\
\text { English (91,4\%) }\end{array}$ \\
\hline b) & 2 & Students never watch television programs in English (16,7\%) \\
\hline c) & 2 & Students never talk to native speakers of English or foreigners (41,6\%) \\
\hline d) & 3 & Students have never attended activities in English (75\%) \\
\hline e) & 3 & Students have a short concentration while communication (58,3\%) \\
\hline f) & 2 & $\begin{array}{l}\text { Students do not get confuse/ headaches while communication in } \\
\text { English (91,7\%) }\end{array}$ \\
\hline
\end{tabular}


| Volume: 2 | Number: 2 | October 2017 | E-ISSN: 2503 - 4405| P-ISSN: 2580-3441|

\begin{tabular}{|c|c|c|}
\hline Items & Modus & Interpretation \\
\hline g) & 2 & $\begin{array}{l}\text { Students do not have knowledge of the specific topic of communication } \\
\text { while communication in English }(41,7 \%)\end{array}$ \\
\hline h) & 3 & Students rarely take notes while communication in English $(58,3 \%)$ \\
\hline i) & 2 & $\begin{array}{l}\text { After listening, Students cannot perform communication activity } \\
\text { without discussing in pair or group of classmates }(41,7 \%)\end{array}$ \\
\hline j) & 2 & $\begin{array}{l}\text { Students never make consultation with teacher with my problems } \\
\text { inside and outside classroom }(33,3 \%)\end{array}$ \\
\hline
\end{tabular}

From the data above, the researcher got the result of questionnaire for obtaining information about students' learning strategies. The students had English learning strategy through audio-visual media. The students used this learning strategy because they had only a short communication in English and they felt confuse while communication in English. The researcher assumed that they had to develop self-confident from passive learning strategy into active learning strategy inside or outside classroom.

Based on students' need, the researcher gave some practice communication materials which had correlation to their field and the things related to their future job in course book with easy and simple activities because in English for nursing 1 was introduction all things about nursing that occurred in hospitals or other health services.

Table 4. Teacher's Teaching Methods

\begin{tabular}{|l|l|l|}
\hline Items & Modus & Interpretation \\
\hline \multicolumn{2}{|l|}{ Teacher's Learning Strategies } \\
\hline a) & 2 & \multicolumn{2}{l|}{ the teacher speaks English too fast $(29,1 \%)$} \\
\hline b) & 2 & the teachers' pronunciation is not clear and accurate (16,7\%) \\
\hline c) & 2 & the teacher teaches English learning strategies in listening (91,7\%) \\
\hline d) & 2 & $\begin{array}{l}\text { the teacher never teaches English learning strategies in speaking } \\
(12,5 \%)\end{array}$ \\
\hline e) & 2 & the teacher teaches English learning strategies in reading (91,7\%) \\
\hline f) & 2 & the teacher teaches English learning strategies in writing (91,7\%) \\
\hline g) & 2 & the teacher uses too much Indonesian to explain the tasks in teaching \\
\hline
\end{tabular}


| Volume: 2 | Number: 2 | October 2017 | E-ISSN: 2503 - 4405| P-ISSN: 2580-3441|

\begin{tabular}{|l|l|l|}
\hline Items & Modus & Interpretation \\
\hline h) & 2 & $\begin{array}{l}\text { learning process (29,2\%) } \\
\text { questions and discuss the learning tasks (20.9\%) }\end{array}$ \\
\hline i) & 2 & $\begin{array}{l}\text { the teacher has never encouraged the students to practice } \\
\text { communication skills as self-learning (12,5\%) }\end{array}$ \\
\hline j) & 3 & $\begin{array}{l}\text { the teacher has helped me with my learning problems inside and } \\
\text { outside the classroom (75\%) }\end{array}$ \\
\hline k) & 3 & $\begin{array}{l}\text { the teacher enjoys speaking English without caring about the students' } \\
\text { interest and understanding (25\%) }\end{array}$ \\
\hline l) & 2 & $\begin{array}{l}\text { the teacher never use different methods in teaching English to } \\
\text { motivate the students (16,7\%) }\end{array}$ \\
\hline m) & 2 & $\begin{array}{l}\text { there are not enough for communication in pair and group work } \\
\text { activities taught by the teacher (79,2\%) }\end{array}$ \\
\hline
\end{tabular}

From the data above, the researcher got the result of questionnaire for obtaining information about teacher's teaching methods. In other words, that the teacher had taught English based on lesson plan and manual written in course book. The teacher explained the materials with standard speed in speaking and gave repetition to important expression and vocabularies, sometimes the teacher explain in Bahasa for understanding the materials when the students did not catch the clue, the teacher gave motivation to learn English because by giving opportunity to practice developing communication skills with their classmates in class activity either individually, work in pairs or in a small group discussion. Some methods that the teacher teaches as strategies such as brainstorming discover learning, presentation, or role play/performance.

The researcher assumed that the way of teaching method had met the students' needs because the result showed that the students accepted the standard teaching method in teaching learning process.

Table 5. Classroom Environment

\begin{tabular}{|l|l|l|}
\hline Items & Modus & Interpretation \\
\hline \multicolumn{2}{|l|}{ Classroom Environment } \\
\hline
\end{tabular}


| Volume: 2 | Number: 2 | October 2017 | E-ISSN: 2503 - 4405| P-ISSN: 2580-3441|

\begin{tabular}{|c|c|c|}
\hline a) & 2 & $\begin{array}{l}\text { Classroom environment does not make students shy and worried } \\
(91,7 \%)\end{array}$ \\
\hline b) & 2 & Other students laugh at me if I answer the question wrong $(12,5 \%)$ \\
\hline c) & 3 & $\begin{array}{l}\text { If Students do not pay attention to the lecturing, my learning process } \\
\text { will not be good }(91,7 \%)\end{array}$ \\
\hline d) & 3 & $\begin{array}{l}\text { Students disagree if Some students talk or make noises while the } \\
\text { teacher are explaining or making communication }(91,7 \%)\end{array}$ \\
\hline
\end{tabular}

From the data above, the researcher got the result of questionnaire for obtaining information about classroom environment. The classroom environment was conducive in teaching learning process. The students respected to other students and also to the teacher, and pay attention to the teacher while explaining and communication. The researcher assumed that the students needed motivation to be brave in expressing the idea while the teacher asking a question.

The teacher created respects each other among students and also motivated to be brave in expressing their ideas during teaching learning process. Those reasons was useful for them in work place later because serving sick people and doing nursing care which was intended good attitude as a nurse which is showing the matters of describing good communication practice.

Table 6 Classroom Facilities

\begin{tabular}{|l|l|l|l|}
\hline \multicolumn{2}{|l|}{ Items } & Modus & Interpretation \\
\hline \multicolumn{2}{|l|}{ Classroom Facilities } \\
\hline a) & 2 & Classroom size is too large $(41,7 \%)$ \\
\hline b) & 2 & Classroom is very noisy $(25 \%)$ \\
\hline c) & 2 & Time allocated for communication activities is limited $(37,5 \%)$ \\
\hline d) & 2 & Audio in the classroom is not effective $(25 \%)$ \\
\hline e) & 2 & Learning module is not effective $(29,2 \%)$ \\
\hline
\end{tabular}

From the data above, the researcher got the result of questionnaire for obtaining information about classroom facilities. This data showed that the classroom facilities were appropriate to support teaching learning process. The researcher assumed the classroom facilities support the students' activities in 
| Volume: 2 | Number: 2 | October 2017 | E-ISSN: 2503 - 4405| P-ISSN: 2580-3441|

classroom and the numbers of students were ideal because every student got opportunities to participate in communication activities.

The classroom consisted of 24 students and the classroom facilities are 1 unit of computer with Wi-Fi hotspot network, LCD projector, audio system, beside that every student has personal laptop. Those facilities were used to support students' learning especially when discover learning activities. Beside that every student has learning module that helped them easily learning by them-selves before the teacher explain the material in teaching learning process.

Obtaining Observation

In the process of English teaching learning, a teacher often faces some problems, such as students' low motivation and students' poor capability in language skills. Students are not interested in English since they consider it as a difficult and boring subject. They seem to have a heavy burden when the teacher asks them to write a composition, doing presentation or role-plays to practice communicative skills.

In this research, it leads the researcher (also as the teacher) to observe the students of 3-year-nursing study program, STIKES RS Baptis Kediri in order to know the causes of the problem, which was conducted on March, 8, 2017. The result of the observation showed that in writing skill, the students do not organize their writing well, their ideas are not coherence, they do not use right tenses in the right context, they have lack of vocabulary and their understanding of mechanic is low. So, they cannot continue their writing. They also think that time for writing is limited. Because of these, they become unmotivated and have low interest in writing. Some students even give up and do not try to solve their problem. In contrary, the students like to listen from the teacher's explanation without giving questioning feedback; it becomes teacher center learning because of passive classroom situation. They like to read the materials in their handbook given by the teacher, but when the teacher asks them to answer the questions or discuss to make a composition, it seem they prefer discuss other things so that they need a lot of times to finish it. Even, in speaking skill, they seem that they don't have selfconfident.

\section{Reviewing of Related Literature}


| Volume: 2 | Number: 2 | October 2017 | E-ISSN: 2503 - 4405| P-ISSN: 2580-3441|

Doing this step, the researchers did reviewing related literature by recheck the contents of already existing syllabus and other relevant document such as curriculum The institutional curriculum of 3 year nursing program for Mata KuliahPengembangandanKepribadian (MPK) consist of 6 credits that were distributed in semester 1, English (MPK 1205) for 2 credits; semester 2, English for Nursing I (MPK 2206) for 2 credits; and semester 3, English for Nursing II (MPK 3207) for 2 credits. It seemed that English for Special Purposes (ESP on Nursing was important for the students. It was appropriate for preparing students' language competency as vocational nurses.

Particularly in English for ESP Nursing, the competency elements that must be achieved were understanding speaking in nursing, reporting in nursing and presentation of nursing activity and its situation related to nursing. The teacher might have different interpretation one to another according to these competencies. Based on this concept so the researchers proposed communicative language teaching (CLT) approach that developed communication materials which had correlation to nursing field in the instructional materials based on nursing process (assessment, nursing diagnosis, planning, implementation, and evaluation).

Meanwhile reviewing previous syllabus done to check relevant and appropriate materials taught in first semester. The researchers found that the students had received theory of nursing process. According to researchers, the subject was appropriately placed in second semester.

To help the students be in active learning, Burns and Erikson (2001) summarize there are five approaches, which are worth implementing in a language curriculum: problem based learning, cooperative learning, project based learning, service learning, and work-based learning. In the Standard ESP curriculum, the aspects covered are on activating students activeness in experiential learning based on the contents they have. So, problem based learning, project based learning, and service learning are types of learning that are helpful for the students to improve their English proficiency by doing something with their English to do something they really know.

\section{Development of Teaching Materials (Book Mapping)}

76| ENGLISH EDUCATION

Journal of English Teaching and Research 
From result of problem identification, get information from requirement analysis. Theresearcher developed a teaching material consisting of 4 chapters. Researchers include four language skills arranged in textbooks. All language skills were integrated into a single book followed by learning outcomes and indicators. Learning outcomes and indicators were developed based on the elements of competence consisting of speaking comprehension in nursing, nursing reporting and presentation of nursing activities and situations related to nursing care. Here is the development of teaching materials in research development based on competence in implementing nursing care (STIKES Baptist Hospital Kediri, 2016) consisting of: (1) Nursing Assessment, (2) Nursing Diagnosis, (3) Nursing Intervention \& Implementation, and (4) Nursing Evaluation.

Result of Expert Validation

There were three experts involved in this step. 1 first-expertwas in English Education, 2 second-expert were innursing education at STIKES of Baptist Hospital Kediri, and 1 third-expert was a hospital practitioner. Consultation with experts about developing material was needed because nursing students used the material. So, the book should fit their needs and the nursing profession. The book should prepare them to become professional nurses in the future. The results of the consultation make the textbook better. Evaluations for expert validation include content, exercises, communications, and general elements, as well as whole comments about textbooks.Quantitative evaluation results from all three experts and one hospital practitioner were reflected in the following tables.

Table 7 Result of Expert Validation on Content

\begin{tabular}{|c|c|c|c|c|c|c|c|c|c|c|c|c|}
\hline \multicolumn{13}{|c|}{ Expert Validation } \\
\hline \multirow[b]{2}{*}{ No. } & \multicolumn{8}{|c|}{ A. Contents } & \multirow{2}{*}{$\begin{array}{l}\text { Tot } \\
\text { al }\end{array}$} & \multirow{2}{*}{$\begin{array}{l}\text { Avera } \\
\text { ge }\end{array}$} & \multirow{2}{*}{$\begin{array}{l}\text { Scor } \\
\text { e }\end{array}$} & \multirow[b]{2}{*}{ Description } \\
\hline & \begin{tabular}{l|lll}
1 & 2 & 3 & 4
\end{tabular} & 5 & 6 & 7 & 8 & 9 & 10 & 11 & & & & \\
\hline & & & & & & & & & & & & $\begin{array}{l}\text { Needed re- } \\
\text { arrange } \\
\text { layout and } \\
\text { sub- }\end{array}$ \\
\hline 1 & $\begin{array}{llll}3 & 3 & 4 & 4\end{array}$ & 3 & 3 & 4 & 3 & 4 & 4 & 4 & 39 & 3,5 & 4 & chapters \\
\hline 2 & $\begin{array}{llll}3 & 3 & 3 & 4\end{array}$ & 4 & 4 & 3 & 3 & 3 & 3 & 3 & 36 & 3,3 & 4 & \\
\hline
\end{tabular}


| Volume: 2 | Number: 2 | October 2017 | E-ISSN: 2503 - 4405| P-ISSN: 2580-3441|

\begin{tabular}{|c|c|c|c|c|c|c|c|c|c|c|c|c|c|}
\hline 3 & \begin{tabular}{l|ll|}
3 & 3 & 3
\end{tabular} & 3 & 3 & 3 & 3 & 3 & 3 & 3 & 2 & 32 & 2,9 & 3 & \\
\hline 4 & $\begin{array}{lll}3 & 3 & 2\end{array}$ & 3 & 3 & 2 & 2 & 2 & 2 & 3 & 2 & 27 & 2,4 & 3 & $\begin{array}{l}\text { Needed } \\
\text { arrangemen } \\
t \text { of sub } \\
\text { chapter. . }\end{array}$ \\
\hline $\begin{array}{l}\text { Averag } \\
\text { e }\end{array}$ & $\begin{array}{lll} & 3 & 3 \\
3 & & \end{array}$ & $\begin{array}{l}3, \\
5\end{array}$ & $\begin{array}{l}3,2 \\
5\end{array}$ & 3 & 3 & $\begin{array}{r}2, \\
75\end{array}$ & 3 & $\begin{array}{r}3, \\
25\end{array}$ & $\begin{array}{r}2, \\
75\end{array}$ & & 3,02 & 3,5 & \\
\hline $\begin{array}{l}\text { Descri } \\
\text { ption }\end{array}$ & & & & & & & & & & & $\begin{array}{l}\text { Very } \\
\text { Good }\end{array}$ & $\begin{array}{l}\text { Very } \\
\text { Goo } \\
\text { d }\end{array}$ & \\
\hline
\end{tabular}

Table 8 Result of Expert Validation on Exercises

\begin{tabular}{|c|c|c|c|c|c|c|c|c|c|c|c|}
\hline \multirow[b]{2}{*}{ No } & \multicolumn{7}{|c|}{ B. Exercises } & \multirow{2}{*}{$\begin{array}{l}\text { Tot } \\
\text { al }\end{array}$} & \multirow{2}{*}{$\begin{array}{l}\text { Avera } \\
\text { ge }\end{array}$} & \multirow{2}{*}{$\begin{array}{l}\text { Scor } \\
\text { e }\end{array}$} & \multirow[b]{2}{*}{ Description } \\
\hline & 1 & 2 & 3 & 4 & 5 & 6 & 7 & & & & \\
\hline 1 & 4 & 4 & 3 & 3 & 3 & 3 & 4 & 24 & 3,4 & 4 & Very good \\
\hline 2 & 4 & 3 & 3 & 3 & 3 & 3 & 3 & 22 & 3,1 & 4 & \\
\hline 3 & 3 & 3 & 3 & 3 & 3 & 3 & 3 & 21 & 3 & 3 & \\
\hline 4 & 3 & 2 & 3 & 2 & 3 & 2 & 2 & 17 & 2,4 & 3 & properly \\
\hline Average & $\begin{array}{c}3, \\
5\end{array}$ & $\begin{array}{l}3,2 \\
5\end{array}$ & 3 & $\begin{array}{l}2,75 \\
3\end{array}$ & 3 & $\begin{array}{l}2, \\
7\end{array}$ & 3 & & 2,97 & 3,5 & \\
\hline $\begin{array}{l}\text { Descripti } \\
\text { on }\end{array}$ & & & & & & & & & Good & $\begin{array}{l}\text { Ver } \\
\text { y } \\
\text { Goo } \\
\text { d }\end{array}$ & \\
\hline
\end{tabular}

Table 9 Result of Expert Validation on Communications

\begin{tabular}{|c|c|c|c|c|c|c|c|c|c|c|c|c|c|c|}
\hline \multirow[b]{2}{*}{ No } & \multicolumn{10}{|c|}{ C.Communications } & \multirow{2}{*}{$\begin{array}{l}\text { Tot } \\
\text { al }\end{array}$} & \multirow{2}{*}{$\begin{array}{l}\text { Avera } \\
\text { ge }\end{array}$} & \multirow{2}{*}{$\begin{array}{l}\text { Scor } \\
\text { e }\end{array}$} & \multirow{2}{*}{$\begin{array}{l}\text { Descripti } \\
\text { on }\end{array}$} \\
\hline & 1 & 2 & 3 & 4 & 5 & 6 & 7 & 8 & 9 & 0 & & & & \\
\hline 1 & 4 & 3 & 3 & & 3 & 3 & 3 & 3 & 3 & 3 & 31 & 3,1 & 4 & $\begin{array}{l}\text { More } \\
\text { exercises } \\
\text { properly }\end{array}$ \\
\hline
\end{tabular}

78| ENGLISH EDUCATION

Journal of English Teaching and Research 
| Volume: 2 | Number: 2 | October 2017 | E-ISSN: 2503 - 4405| P-ISSN: 2580-3441|

\begin{tabular}{|c|c|c|c|c|c|c|c|c|c|c|c|c|c|c|}
\hline & & & & & & & & & & & & & & $\begin{array}{l}\text { based on } \\
\text { real fact. }\end{array}$ \\
\hline 2 & 2 & 2 & 3 & 4 & 4 & 3 & 4 & 3 & 3 & 3 & 31 & 3,1 & 4 & \\
\hline 3 & 3 & 3 & 3 & 3 & 3 & 3 & 3 & 3 & 3 & 3 & 30 & 3 & 3 & \\
\hline 4 & 2 & 3 & 2 & 2 & 3 & 3 & 3 & 3 & 3 & 3 & 27 & 2,7 & 3 & $\begin{array}{l}\text { There } \\
\text { were } \\
\text { communi } \\
\text { cative } \\
\text { excerces }\end{array}$ \\
\hline $\begin{array}{l}\text { Aver } \\
\text { age }\end{array}$ & $\begin{array}{l}2,7 \\
5\end{array}$ & $\begin{array}{l}2,7 \\
5\end{array}$ & $\begin{array}{l}2,7 \\
5\end{array}$ & 3 & $\begin{array}{l}3, \\
25\end{array}$ & 3 & $\begin{array}{l}3,2 \\
5\end{array}$ & 3 & 3 & 3 & & 3,0 & 3,5 & \\
\hline $\begin{array}{l}\text { Desc } \\
\text { ript- } \\
\text { ion }\end{array}$ & & & & & & & & & & & & Good & $\begin{array}{l}\text { Very } \\
\text { goo } \\
\text { d }\end{array}$ & \\
\hline
\end{tabular}

Table 10 Result of Expert Validation on General Element

\begin{tabular}{|c|c|c|c|c|c|c|c|c|c|c|c|c|c|c|}
\hline \multirow[b]{2}{*}{ No } & \multicolumn{10}{|c|}{ D. General Element } & \multirow{2}{*}{$\begin{array}{l}\text { Tot } \\
\text { al }\end{array}$} & \multirow{2}{*}{$\begin{array}{l}\text { Avera } \\
\text { ge }\end{array}$} & \multirow{2}{*}{$\begin{array}{l}\text { Sco } \\
\text { re }\end{array}$} & \multirow{2}{*}{$\begin{array}{l}\text { Descript } \\
\text { ion }\end{array}$} \\
\hline & 1 & 2 & 3 & 4 & 5 & 6 & 7 & 8 & 9 & 10 & & & & \\
\hline 1 & 3 & 3 & 2 & 4 & 3 & 3 & 3 & 4 & 3 & 2 & 30 & 3 & 3 & $\begin{array}{l}\text { Need } \\
\text { rearrang } \\
\text { e layout } \\
\text { and } \\
\text { consiste } \\
\text { ncy of } \\
\text { vocabula } \\
\text { ry level } \\
\text { on every } \\
\text { chapter }\end{array}$ \\
\hline 2 & 4 & 3 & 4 & 4 & 3 & 4 & 3 & 4 & 4 & 4 & 37 & 3,7 & 4 & \\
\hline 3 & 3 & 3 & 3 & 3 & 3 & 3 & 3 & 3 & 3 & 3 & 30 & 3 & 3 & $\begin{array}{l}\text { The } \\
\text { book } \\
\text { was }\end{array}$ \\
\hline
\end{tabular}

YoyokFebrijanto, Sandy Kurniajati| 79 


\begin{tabular}{|c|c|c|c|c|c|c|c|c|c|c|c|c|c|c|}
\hline & & & & & & & & & & & & & & $\begin{array}{l}\text { relevant } \\
\text { used for } \\
\text { nursing } \\
\text { students }\end{array}$ \\
\hline 4 & 2 & 3 & 3 & 3 & 4 & 3 & 3 & 2 & 2 & 2 & 27 & 2,7 & 3 & $\begin{array}{l}\text { Stillsom } \\
\text { e words } \\
\text { were } \\
\text { difficult } \\
\text { in terms. }\end{array}$ \\
\hline $\begin{array}{l}\text { Aver } \\
\text { age }\end{array}$ & 3 & 3 & 3 & 3,5 & $\begin{array}{l}3,7 \\
5\end{array}$ & $\begin{array}{l}3,7 \\
5\end{array}$ & 3 & $\begin{array}{l}3,2 \\
5\end{array}$ & 3 & $\begin{array}{l}2,7 \\
5\end{array}$ & & 3,0 & $\begin{array}{l}3,2 \\
5\end{array}$ & \\
\hline $\begin{array}{l}\text { Dsscr } \\
\text { ipt- } \\
\text { ion }\end{array}$ & & & & & & & & & & & & Good & $\begin{array}{l}\text { Ver } \\
\text { y } \\
\text { Go } \\
\text { od }\end{array}$ & \\
\hline
\end{tabular}

Consultation with experts about teaching material was really needed because students used the textbook. The consultation was conducted on June 18, 2017. The results of the consultation make teaching materials better. Evaluations for expert validation are contents, exercises, communication, general elements, as well as overall comments on teaching materials.

The first evaluation is about the content. Of the three experts above, they rate very good for content. From table 7 , showed the validation results of the expert about the textbook content was very good (with an average of 3.5), which means no revision is required. The input from the expert includes "the need for layout arrangement and arrangement of sub-chapters". Experts think that the contents of the book speak about the actual topic of nursing and its content accommodates the curriculum of the nursing studies program and their content are well organized and challenges the learners to think critically about English in care. Although, the expert agrees that the content is very good, it still provides some recommendations to make the book better by stating that the textbook content reflects certain English in the care that students often use in both teaching 
and learning activities and clinical practice as reflected in sub-chapter.From the recommendations of experts, researchers review and revise sub-chapters in each chapter by adjusting the four language skills with a focus on nursing procedures and nursing documentation that support nursing content.

The second evaluation is about exercise. Exercise as the main aspect of this textbook because it talks about student activity. From table 8, the results of the expert validation of the exercises in the textbooks are very good (with an average of 3.5), they are considered very good and good for practice. The first expert thinks that exercising was according to topics and activities encourages students to speak in English, in understanding the practice in textbooks, the expert states that having no difficulty in understanding the exercises, the practice is not difficult and not easy, it is appropriate for students, and in completing the exercise in this textbook, the expert states that the student is able to complete all the exercises. Although, the three experts agreed that the exercises were excellent and good at understanding and completing the practice in textbooks, but he also gave some recommendations to make the book better by saying to try to make a shorter example of patient review.

The third evaluation is about communication. Communication is the main aspect of this book because it talks about students' communication skills and activities. From table 9, the result of expert validation about textbook communication is very good (with average 3.5). Input from the expert to be enhanced communication practice in real situations (condition of student practice at the Hospital). The first expert is considered very good and good for communication. He thinks that the communicative activity of the book captures the true daily life, the expert feels a useful expression for communication at the hospital, especially in nursing terms, and the conversation captures the true and understandable conversations in everyday life that can be applied to nursing terms. Though, the third expert agrees that communication is excellent in textbooks because the communication of this book is useful for learning in a particular language setting and the conversation is not difficult to understand, but it also provides some recommendations to make the book better. By listing some meaningful terms in nursing diagnoses as an application of nursing science 
especially in nursing documentation.From an expert's recommendation, the researcher examines and revises and adds the term in an appropriate nursing diagnosis in chapter 2 by distinguishing meaning in diagnosis especially medical diagnosis and nursing diagnoses.

The fourth evaluation is about the common elements. From table 10, the results of expert valiadation about the general elements of textbooks are very good (with an average of 3.25). The expert input is the need for layout layout and vocabulary consistency on each chapter and still found the words which difficult to interpret. From the expert's recommendation, the researcher revises the layout arrangement by differentiating the sub-chapter from either bold or italic writing, while for vocabulary consistency with difficult words accompanied by a particular meaning in the "vocabulary" sub-section in accordance with the evaluation .

\section{Try Out Results}

After revising the material, the material was tested in this study twice in the class. This procedure is done to obtain inputs for teaching materials and to know acceptance or acceptability of teaching materials. The researchers chose two units to be tested namely Chapter 1 Assessment (Nursing Assessment) and Chapter 2 Nursing Diagnosis (Nursing Diagnosis). Researchers choose these units because they think the unit is very important to learn. The topic relates to the daily activities of the nurse. But that does not mean other units are not important either. Researchers conducted trials on June 26 and 28, 2017.

Table11 Result of Try-Out to Students

\begin{tabular}{|c|c|c|c|c|c|c|c|c|c|c|c|c|c|}
\hline \multicolumn{14}{|c|}{ Try-out } \\
\hline \multirow[b]{2}{*}{ No } & \multicolumn{10}{|c|}{ Items } & \multirow{2}{*}{$\begin{array}{l}\text { Tota } \\
l\end{array}$} & \multirow{2}{*}{$\begin{array}{l}\text { Avera } \\
\text { ge }\end{array}$} & \multirow[b]{2}{*}{ Score } \\
\hline & 1 & 2 & 3 & 4 & 5 & 6 & 7 & 8 & 9 & 10 & & & \\
\hline 1 & 4 & 3 & 3 & 3 & 3 & 4 & 2 & 3 & 2 & 2 & 29 & 2,9 & 3 \\
\hline 2 & 3 & 2 & 3 & 2 & 2 & 2 & 3 & 3 & 4 & 3 & 27 & 2,7 & 3 \\
\hline 3 & 3 & 4 & 3 & 2 & 4 & 2 & 2 & 3 & 4 & 3 & 30 & 3 & 3 \\
\hline 4 & 3 & 4 & 3 & 3 & 3 & 2 & 2 & 3 & 3 & 3 & 29 & 2,9 & 3 \\
\hline 5 & 3 & 3 & 4 & 3 & 3 & 3 & 3 & 4 & 3 & 4 & 33 & 3,3 & 3 \\
\hline 6 & 3 & 3 & 4 & 4 & 3 & 3 & 4 & 3 & 4 & 4 & 35 & 3,5 & 4 \\
\hline
\end{tabular}

82| ENGLISH EDUCATION 
| Volume: 2 | Number: 2 | October 2017 | E-ISSN: 2503 - 4405| P-ISSN: 2580-3441|

\begin{tabular}{|c|c|c|c|c|c|c|c|c|c|c|c|c|c|}
\hline \multicolumn{14}{|l|}{ Try-out } \\
\hline \multirow[b]{2}{*}{ No } & \multicolumn{10}{|c|}{ Items } & \multirow{2}{*}{$\begin{array}{l}\text { Tota } \\
1\end{array}$} & \multirow{2}{*}{$\begin{array}{l}\text { Avera } \\
\text { ge }\end{array}$} & \multirow[b]{2}{*}{ Score } \\
\hline & 1 & 2 & 3 & 4 & 5 & 6 & 7 & 8 & 9 & 10 & & & \\
\hline 7 & 3 & 3 & 3 & 3 & 3 & 2 & 3 & 3 & 2 & 2 & 27 & 2,7 & 3 \\
\hline 8 & 3 & 2 & 4 & 1 & 3 & 4 & 3 & 3 & 3 & 2 & 28 & 2,8 & 3 \\
\hline 9 & 4 & 4 & 3 & 3 & 2 & 3 & 3 & 3 & 3 & 4 & 32 & 3,2 & 4 \\
\hline 10 & 3 & 3 & 4 & 3 & 4 & 4 & 3 & 2 & 4 & 4 & 34 & 3,4 & 4 \\
\hline 11 & 3 & 4 & 3 & 3 & 3 & 4 & 2 & 3 & 3 & 2 & 30 & 3 & 3 \\
\hline 12 & 4 & 1 & 3 & 1 & 3 & 4 & 1 & 2 & 2 & 1 & 22 & 2,2 & 3 \\
\hline 13 & 3 & 2 & 4 & 3 & 3 & 2 & 3 & 3 & 2 & 3 & 28 & 2,8 & 3 \\
\hline 14 & 3 & 2 & 4 & 3 & 2 & 3 & 3 & 4 & 3 & 3 & 30 & 3 & 3 \\
\hline 15 & 1 & 2 & 3 & 4 & 3 & 2 & 1 & 2 & 3 & 3 & 24 & 2,4 & 3 \\
\hline 16 & 3 & 3 & 4 & 3 & 4 & 2 & 3 & 3 & 4 & 4 & 33 & 3,3 & 4 \\
\hline 17 & 2 & 2 & 3 & 3 & 3 & 3 & 3 & 3 & 3 & 3 & 28 & 2,8 & 3 \\
\hline 18 & 2 & 2 & 3 & 4 & 3 & 3 & 3 & 3 & 2 & 2 & 27 & 2,7 & 3 \\
\hline 19 & 3 & 3 & 4 & 3 & 4 & 2 & 2 & 3 & 3 & 2 & 29 & 2,9 & 3 \\
\hline 20 & 3 & 2 & 4 & 2 & 3 & 3 & 4 & 3 & 2 & 4 & 30 & 3 & 3 \\
\hline 21 & 2 & 1 & 2 & 3 & 2 & 3 & 2 & 1 & 2 & 2 & 20 & 2 & 2 \\
\hline 22 & 3 & 3 & 2 & 3 & 2 & 2 & 4 & 3 & 3 & 4 & 29 & 2,9 & 3 \\
\hline 23 & 3 & 3 & 3 & 4 & 4 & 3 & 3 & 3 & 3 & 2 & 31 & 3,1 & 4 \\
\hline 24 & 2 & 1 & 3 & 3 & 4 & 4 & 2 & 2 & 2 & 3 & 26 & 2,6 & 3 \\
\hline Average & $\begin{array}{l}2, \\
9\end{array}$ & $\begin{array}{l}2, \\
7\end{array}$ & $\begin{array}{l}3, \\
4\end{array}$ & 3 & $\begin{array}{l}3,2 \\
5\end{array}$ & $\begin{array}{l}3, \\
1\end{array}$ & $\begin{array}{l}2, \\
9\end{array}$ & $\begin{array}{l}3, \\
1\end{array}$ & $\begin{array}{l}3, \\
2\end{array}$ & $\begin{array}{l}3, \\
3\end{array}$ & & 2,9 & 3,2 \\
\hline $\begin{array}{l}\text { Descripti } \\
\text { on }\end{array}$ & & & & & & & & & & & & Good & $\begin{array}{l}\text { Very } \\
\text { Good }\end{array}$ \\
\hline
\end{tabular}

Researchers want to have some improvements in learning materials. Researchers created several models of new activities or tasks in the development of materials. It is more interesting for students to make students more interested in learning. Several models of new activities or tasks are proposed in the CTL approach that focuses on communication practice, therefore researchers contribute to material feature conversations, phrases used in the field of nursing YoyokFebrijanto, Sandy Kurniajati| 83 
as speech enhancement, and vocabulary related to medical / nursing skills as improved reading skills, writing ability. Researchers follow ideas written syllabus and material mapping. Researchers think that 4 written language skills in learning materials. The students are expected to be motivated to follow all activities because the textbooks are communicative and there are integrated skills there. All language skills are integrated into a single book followed by learning outcomes and indicators.

Learning outcomes and indicators are developed on the basis of competence elements consisting of speaking comprehension in nursing, nursing reporting and presentation of nursing activities and situations related to nursing to help students understand the material well. Based on this idea, researchers revise the four chapters that describe the outcomes and indicators of learning and each topic is arranged chronologically. It starts with a nursing assessment whereby students get information about nursing and patient health until students learn nursing activities up to nursing evaluation as the main topics in this product and make nursing documentation.

In addition, Harmer (2007: 369) argues that the type of ESP teaching materials should be integrated or called multi ESP learning materials. This makes the researcher confident about the model of teaching materials written. It combines the four language skills into integrated skills, and the book is communicative for students as ESP students.

The material that develops above shows that students need English that has a correlation with their field related to nursing care. So, they need nursing English since they studied in college. English for nursing is very beneficial to them.

As Hutchinson and Walter (1994: 18) state that ESP is a language learning approach, based on the needs of learners. So by giving English for care as their needs in their classes, it is easier to understand the material provided and tailored to the ESP approach. ESP training is an approach to teaching English for nonEnglish students to meet their needs in English learning related to their specialization. In this case, to provide what they need, the English teaching materials developed by researchers determine English for Nursing. This subject has a correlation with the field and according to their needs in their future carrier.

84| ENGLISH EDUCATION 
| Volume: 2 | Number: 2 | October 2017 | E-ISSN: 2503 - 4405| P-ISSN: 2580-3441|

Instructional materials talk about their background knowledge, life experiences and their real task in care. As a result, the students as users of this textbook got their needs by practicing more exercises through this textbook. Developing materials also give grammatical focus in each chapter. This need is also given to the teaching materials by giving the grammar material in each unit. Researchers provide easy grammar material, followed by switching to more difficult grammar. This reason by giving easy grammar first, it provides a solid foundation for learning ESP in their classes.

From table 11, the result of students' try out to give the decision of the product quality, the average score was 3.2, it meant the materials was acceptable and eligible to be used by the nursing students as teaching learning process. In conclusion, the final product can be used as a model of instructional materials to teach English nursing as ESP materials.

\section{CONCLUSION AND RECOMENDATION}

Conclusion

In conclusion, the result from data of need analysis showed that most students agree to develop English materials that are suitable and related to their profession with 4 language skills using communicative language teaching based on nursing process (assessment, nursing diagnosis, planning, implementation, and evaluation). Developing teaching/learning materials has been described from the points of view of the definition, the principles, the procedure, and the practical undertaking of them with the case of developing learning materials for ESP. Developing teaching/learning materials for ESP is more demanded than that for general English because the availability of the ESP learning materials in public is very rare. Because of this, it is suggested that teachers of ESP developtheir own specific materials for their own target language learners. In developing the ESP learning materials, every teacher can follow any approach he/she is familiar with and he/she can develop his/her teaching materials by applying the principles and procedures of language teaching materials including formulating their teaching objectives and syllabus, adapting and or supplementing the existing materials, and or creating their own materials. There may be some other possible ways of 
| Volume: 2 | Number: 2 | October 2017 | E-ISSN: 2503 - 4405| P-ISSN: 2580-3441|

developing teaching/learning materials than the one described in this paper. As the consequence, the same level of specific language for the same level of students may have different teaching/learning materials especially if the materials developer and the proficiency level of the students are different.

Therefore, there will never be perfect teaching/learning materials that can be used anywhere, anytime for the same level of students. I strongly suggest that a teacher develop his/her own teaching materials for his/her own specific target learners. If a teacher has to use a textbook for some reason, still s/he has to adjust it with the target learners. There may be some parts of the textbook, which are not exactly suitable for the target learners. Recomendation

The researchers gave some suggestions that the product can be used as a model of instructional materials to teach English nursing for English teachers, and the institution, The product material did not cover all of student's need so the researcher also suggests to use other resources from books or website as discover learning to know more information from the topic discussion. The researcher gives suggestion about product dissemination. This book is also appropriate to use for second semester students of Diploma Nursing Program because they also study English in Nursing I in that semester as main course book or supplementary book. The last, the researcher hopes there are any further development products about ESP material for nursing program. The researcher knows that they are still a lot of topic that canbe developed such as concerning in nursing documentation, procedures in nursing intervention or concerning in nursing care.

\section{REFERENCES}

Arifin, S. \&Kursrianto, A. 2009.SuksesMenulisBuku Ajar danReferensi: TeknikdanStrategiMenjadikanTulisanAndaLayakDiterbitkan. Jakarta: PT Grasindo.

Brown H.D., 2007. Teaching by Principles: An Interactive Approach to Language Teaching. New York: Pearson education Inc.

Gunadi, Kun Aniroh M. 2011.ESP Materials Development: Theory and Practice.Malang: Program PascaSarjanaUniversitasBrawijaya Malang.

86| ENGLISH EDUCATION 
| Volume: 2 | Number: 2 | October 2017 | E-ISSN: 2503 - 4405| P-ISSN: 2580-3441|

Harmer, J. 2007.The Practice of English Language Teaching: Fourth Edition. Edinburg Gate London: Longman Pearson Education ltd.

Latief, M.A,.2013. Research Methods on Language learning an Introduction. $2^{\text {nd }}$ Ed. Malang: UM Press.

Lightbown, PM \&Spada, N. 2001. How Languages are Learned: Second Edition. Oxford: Oxford University Press.

Richards, J.C. 2001. Curriculum Development in Language Teaching.Cambridge: Cambridge University Press.

Richards, J.C. 2006. Communicative Language Teaching Today.Cambridge: Cambridge University Press.

STIKES RS Baptis Kediri. 2016. KurikulumInstitusiBerbasisPerguruanTinggi.

Tomlinson, B. and Matshuhara,H. 2004. Developing language Course Materials.Singapore: SEAMEO RELC.

Willis, D \& Willis, J. 2007.Doing Task-based Teaching.New York: Oxford University Press. 